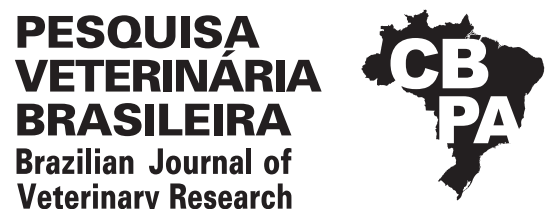

Pesq. Vet. Bras. 40(1):61-71, January 2020 DOI: 10.1590/1678-5150-PVB-6408

Original Article

Small Animal Diseases

ISSN 0100-736X (Print)

ISSN 1678-5150 (Online)

\title{
Primary nonlymphoid gastrointestinal neoplasms in dogs in Rio Grande do Sul ${ }^{1}$
}

\author{
Mônica Slaviero², Fernando F. Argenta ${ }^{2}$, Luiza P. Ehlers² ${ }^{2}$ Cíntia De Lorenzo², \\ Saulo P. Pavarini ${ }^{2}$, David Driemeier ${ }^{2}$ and Luciana Sonne ${ }^{2 *}$ (D)
}

\begin{abstract}
Slaviero M., Argenta F.F., Ehlers L.P., De Lorenzo C., Pavarini S.P., Driemeier D. \& Sonne L. 2020. Primary nonlymphoid gastrointestinal neoplasms in dogs in Rio Grande do Sul. Pesquisa Veterinária Brasileira 40(1)61-71. Setor de Patologia Veterinária, Departamento de Patologia Clínica Veterinária, Faculdade de Veterinária, Universidade Federal do Rio Grande do Sul, Av. Bento Gonçalves 9090, Prédio 42505, Porto Alegre, RS 91540-000, Brazil. E-mail: lusonne@yahoo.com.br

Gastrointestinal neoplasms (GIN) are uncommon in dogs, but they mainly show malignant behavior and poor prognosis. The types of GIN in dogs and their frequency, as well as their epidemiological and histopathological characteristics were analyzed through a retrospective study of biopsies from 24.711 dogs from 2005 to 2017. Additionally, histological sections of neoplasms were subjected to immunohistochemistry (IHC) using antibodies against pancytokeratin, vimentin, smooth muscle actin, c-Kit, S-100, CD31, CD79 $\alpha$ cy, and neuron-specific enolase. Of the total samples from dogs analyzed, 88 corresponded to GIN. Neoplasms occurred more frequently in purebred dogs $(64.8 \%, 57 / 88)$, males $(53.4 \%, 47 / 88)$, with a median age of 10 years. The intestine was affected by $84.1 \%(74 / 88)$ of the cases. Of these, the large intestine was the most affected (67.6\%, 50/74). Most of the neoplasms had malignant behavior (88.6\%, 78/88). Regarding the classification of neoplasms, $46.6 \%$ $(41 / 88)$ of the diagnoses corresponded to epithelial, $46.6 \%$ (41/88) were mesenchymal, $5.7 \%(5 / 88)$ were hematopoietic, and $1.1 \%(1 / 88)$ was neuroendocrine. The most frequently diagnosed neoplasms were papillary adenocarcinoma $(19.3 \%, 17 / 88)$, leiomyosarcoma $(17.0 \%, 15 / 88)$, gastrointestinal stromal tumors (GISTs) $(12.5 \%, 11 / 88)$, and leiomyoma $(5.0 \%, 8 / 88)$. Adenocarcinomas were located mainly in the rectum, whereas leiomyosarcomas and GISTs developed mainly in the cecum. Epithelial neoplasms showed a greater potential for lymphatic invasion whereas mesenchymal neoplasms appeared to be more expansive with intratumoral necrosis and hemorrhage. Immunohistochemistry was found to be an important diagnostic technique for the identification of infiltrating cells in carcinomas and an indispensable technique for the definitive diagnosis of sarcomas.
\end{abstract}

INDEX TERMS: Primary nonlymphoid, gastrointestinal neoplasms, dogs, Rio Grande do Sul, Brazil, canine, gastric neoplasm, intestinal neoplasm, histopathology, immunohistochemistry.

RESUMO.- [Neoplasmas gastrointestinais primários não linfoides em cães no Rio Grande do Sul.] Neoplasmas gastrointestinais (NGI) são pouco comuns em cães, mas possuem principalmente comportamento maligno e prognóstico reservado. Os tipos de NGI em cães e sua frequência, bem como características epidemiológicas e histopatológicas foram

\footnotetext{
${ }^{1}$ Received on May 22, 2019.

Accepted for publication on June 6, 2019.

${ }^{2}$ Setor de Patologia Veterinária, Departamento de Patologia Clínica Veterinária, Faculdade de Veterinária, Universidade Federal do Rio Grande do Sul (UFRGS), Av. Bento Gonçalves 9090, Porto Alegre, RS 91540-000, Brazil. *Corresponding author: lusonne@yahoo.com.br
}

analisados por meio de um estudo retrospectivo dos exames de biópsias de 24.711 cães entre os anos de 2005 a 2017. Adicionalmente, cortes histológicos de NGI foram submetidos à técnica de imuno-histoquímica (IHQ), utilizando os anticorpos anti-pancitoqueratina, vimentina, actina de músculo liso, c-Kit, S-100, CD31, CD79 $\alpha$ cy e enolase neurônio específica. Do total de cães analisados, 88 corresponderam a NGI não linfoides. Os neoplasmas ocorreram com maior frequência em cães de raça pura $(64,8 \%, 57 / 88)$, machos $(53,4 \%, 47 / 88)$, com mediana de idade de 10 anos. 0 intestino foi acometido em $84,1 \%$ dos casos (74/88). Destes, o intestino grosso foi o segmento mais afetado $(67,6 \%, 50 / 74)$. A maior parte dos 
neoplasmas tinha comportamento maligno $(88,6 \%, 78 / 88)$. Quanto à classificação, 46,6\% (41/88) dos diagnósticos corresponderam a neoplasmas epiteliais, $46,6 \%(41 / 88)$ mesenquimais, 5,7\% (5/88) hematopoiéticos e 1,1\% (1/88), neuroendócrino. Os neoplasmas mais frequentemente diagnosticados foram adenocarcinoma papilar $(19,3 \%$, $17 / 88)$, leiomiossarcoma $(17,0 \%, 15 / 88)$, tumor estromal gastrointestinal (GIST) $(12,5 \%, 11 / 88)$ e leiomioma $(12,5 \%$, 8/88). Adenocarcinomas localizavam-se principalmente no reto, enquanto leiomiossarcoma e GISTs desenvolveram-se principalmente no ceco. Os neoplasmas epiteliais demonstraram um potencial maior de invasão linfática enquanto que os mesenquimais aparentaram ser mais expansivos, com necrose e hemorragia intratumorais. A imuno-histoquímica mostrou ser uma técnica diagnóstica importante para a identificação de células neoplásicas infiltravas no caso dos carcinomas e uma técnica indispensável para o diagnóstico definitivo de sarcomas.

TERMOS DE INDEXAÇÃO: Neoplasmas gastrointestinais, cães, Rio Grande do Sul, Brasil, caninos, neoplasma gástrico, neoplasma intestinal, histopatologia, imuno-histoquímica.

\section{INTRODUCTION}

Gastrointestinal neoplasms (GIN) are uncommon in dogs, but show malignant behavior and a poor prognosis in most cases (Swann \& Holt 2002, Uzal et al. 2016). The stomach and intestine have the same basic histological structures and therefore exhibit similar primary neoplasms, which are classified as epithelial, neuroendocrine, hematopoietic mesenchymal, and non-hematopoietic mesenchymal tumors (Head et al. 2003).

Although reports of GIN cases and individualized studies of each neoplastic type are not uncommon (Patnaik et al. 1978, 1980a, 1980b, Fonda et al. 1989, La Rock \& Ginn 1997, Ozaki et al. 2002, Paoloni et al. 2002, Bettini et al. 2003, Cohen et al. 2003, Frost et al. 2003, Kupanoff et al. 2006, Hayes et al. 2013), retrospective studies combining all neoplastic types of the gastrointestinal tract of dogs and address histological characteristics and immunohistochemical techniques (IHC) are still scarce (Patnaik et al. 1977, Frgelecová et al. 2014). Little is known about the epidemiological data, anatomical locations of occurrence, and behavior of these neoplasms.

In addition, non-hematopoietic mesenchymal tumors have very similar histological characteristics and until recently, due to the absence of criteria, there have been controversies in defining these neoplasms in veterinary medicine (Munday et al. 2017). This results in inconsistent classification of these neoplasms as gastrointestinal stromal tumors (GISTs), smooth muscle tumors, neural tumors, and fibroblast tumors, which have a wide variety of biological behaviors (La Rock \& Ginn 1997). Human GISTs are currently recognized as a distinct tumor entity with neoplastic cells originating from the interstitial cells of Cajal and expressing c-Kit protein (Kindblom et al. 1998, Miettinen \& Lasota 2001). The correct definition and identification of GISTs has become important after the introduction of Kit-selective tyrosine kinase inhibitor imatinib mesylate for the treatment of these tumors (Van Oosterom et al. 2001, Demetri et al. 2002). Since then studies have reclassified canine gastrointestinal mesenchymal neoplasms based on the human classification criteria mainly through IHC (Frost et al. 2003, Maas et al. 2007, Hayes et al.
2013) with the objective of establishing an accurate diagnosis and determining a more accurate prognosis and treatment.

This study aimed to determine the frequency and types of nonlymphoid GIN in dogs from biopsy specimens diagnosed in the Metropolitan Region of Porto Alegre and to describe their epidemiological, pathological, and immunohistochemical features.

\section{MATERIALS AND METHODS}

From January 2005 to December 2017 the biopsy files of dogs were reviewed, and cases with GIN were selected. Epidemiological aspects such as breed, age, and sex, as well as anatomical location and histopathological characteristics were analyzed and compiled. Gastric and intestinal lymphomas were excluded in the present study. The cases were mainly from the metropolitan area of Porto Alegre, Rio Grande do Sul, Brazil.

The GIN diagnoses of the present study were standardized according to the histological criteria established by the World Health Organization (Head et al. 2003) and the classification proposed by Hayes et al. (2013) for nonlymphoid and nonangiogenic gastrointestinal sarcomas. The mesenchymal neoplasms that are part of the hematopoietic system were separated into a specific category of hematopoietic neoplasms.

Additionally, histological sections of neoplasms were subjected to histopathological routine tests, stained with hematoxylin and eosin (HE), and to immunohistochemistry (IHC); the primary antibodies and the protocols used are specified in Table 1. When necessary, sections of GIN with mesenchymal origin were subjected to special histochemical staining with Masson's Trichrome (MT) and Red-Congo, to identify collagen and amyloid fibers, respectively.

\section{RESULTS}

\section{Epidemiological and general morphological aspects}

From January 2005 to December 2017, 24.711 canine biopsies were processed and evaluated, of which 14.603 had diagnoses of neoplasms. In total, 88 samples corresponded to GIN, accounting for $0.4 \%$ of the total canine biopsies and $0.6 \%$ of the total neoplasm diagnoses. GIN affected pure-bred dogs at $64.8 \%(57 / 88)$ and mixed breed dogs at 32.9\% (29/88). In two cases, the breed was not informed. The most affected breeds were Poodle (8/88), Boxer (5/88), Dachshund (5/88), and Labrador Retriever (4/88). The median age at the time of diagnosis was 10 years with a range of 1.0-17.0 years. The dogs included 47 (53.4\%) males and 39 (44.3\%) females. In two cases, the sex was not informed.

Neoplasms involved the intestine in $84.1 \%$ (74/88) of the cases and the stomach in $15.9 \%(14 / 88)$. The large intestine (LI) was the most affected segment $(67.6 \%, 50 / 74)$, and the small intestine (SI) corresponded to $29.7 \%(22 / 74)$ of cases. In two cases, the affected intestinal segment was not reported and the sample was too small to be determined by histology. Regarding biological behavior, $88.6 \%$ (78/88) of the neoplasms were malignant and $11.4 \%$ were benign $(10 / 88)$.

Epithelial neoplasms corresponded to $46.6 \%$ (41/88) of the diagnoses, mesenchymal to $46.6 \%$ (41/88), hematopoietic to $5.7 \%$ (5/88), and neuroendocrine to $1.1 \%$ (1/88). The main diagnoses of nonlymphoid GIN in dogs of the present study were papillary adenocarcinoma $(19.3 \%, 17 / 88)$, leiomyosarcoma (17.0\%, 15/88), and GIST $(12.5 \%, 11 / 88)$. The complete morphological diagnoses of canines nonlymphoid GIN are described in Table 2, along with the anatomical location and the total number of cases. 
Table 1. Antibodies and immunohistochemical protocols used in canine nonlymphoid gastrointestinal neoplasms

\begin{tabular}{|c|c|c|c|c|c|}
\hline Antibody/code & Clone & Antigenic recovery & Diluition & $\begin{array}{c}\text { Detection } \\
\text { system }\end{array}$ & Chromogen \\
\hline Alpha smooth muscle actin ${ }^{a}$ (M0851) & Monoclonal (1A4) & $20 \mathrm{~min} / 120^{\circ} \mathrm{C}$, plus Tris-EDTA pH 9.0 & $1: 50$ & $\mathrm{MACH}_{4}^{\mathrm{b}}$ & $\mathrm{AEC}^{\mathrm{a}}$ \\
\hline $\mathrm{CD} 1^{\mathrm{a}}(\mathrm{A} 0082)$ & Monoclonal (JC70A) & $3 \mathrm{~min} / 125^{\circ} \mathrm{C}$, plus citrate, $\mathrm{pH} 6.0$ & $1: 800$ & $\mathrm{MACH} 4^{\mathrm{b}}$ & $\mathrm{AEC}^{\mathrm{a}}$ \\
\hline CD117 (c-Kit) ${ }^{a}$ (A04502) & Polyclonal & $40 \mathrm{~min} / 96^{\circ} \mathrm{C}$, plus citrate $\mathrm{pH} 6.0$ & $1: 300$ & $\mathrm{MACH}_{4}^{\mathrm{b}}$ & $\mathrm{AEC}^{\mathrm{a}}$ \\
\hline Neuron-Specific Enolase ${ }^{a}$ (M0873) & Monoclonal (BBS/NC/VI-H14)) & $40 \mathrm{~min} / 96^{\circ} \mathrm{C}$, plus citrate, $\mathrm{pH} 6.0$ & $1: 200$ & MACH $4^{\mathrm{b}}$ & $\mathrm{AEC}^{\mathrm{a}}$ \\
\hline $\operatorname{Vimentin}^{\mathrm{c}}(18-002)^{\mathrm{c}}$ & Monoclonal (V9) & $3 \mathrm{~min} / 125^{\circ} \mathrm{C}$, plus citrate, $\mathrm{pH} 6.0$ & $1: 200$ & $\mathrm{MACH} 4^{\mathrm{b}}$ & $\mathrm{AEC}^{\mathrm{a}}$ \\
\hline
\end{tabular}

Acquisition sources: ${ }^{\mathrm{a}}$ Dako, ${ }^{\mathrm{b}}$ Biocare Medical, ${ }^{\mathrm{c}}$ Invitrogen; MACH 4 = Universal HRP-Polymer, AEC = 3-amino-9-ethylcarbazole.

Table 2. Morphological diagnoses, location and number of cases of nonlymphoid gastrointestinal neoplasms in canines from January 2005 to December 2017

\begin{tabular}{|c|c|c|c|c|c|}
\hline \multirow{2}{*}{ Diagnoses } & \multicolumn{3}{|c|}{ Location } & \multirow{2}{*}{ Total } & \multirow{2}{*}{$\%$ Total } \\
\hline & Stomach & SI & LI & & \\
\hline \multicolumn{6}{|l|}{ Epithelial } \\
\hline Papillary adenocarcinoma & 0 & 2 & 15 & 17 & $19.3 \%$ \\
\hline Mucinous adenocarcinoma & 1 & 3 & 2 & 6 & $6.8 \%$ \\
\hline Undifferentiated adenocarcinoma & 2 & 1 & 2 & 5 & $5.7 \%$ \\
\hline \multicolumn{6}{|l|}{ Mesenchymal } \\
\hline Leiomyosarcoma & 1 & 4 & 9 & $15^{*}$ & $17.0 \%$ \\
\hline Gastrointestinal stromal tumors (GIST) & 0 & 3 & 7 & $11^{*}$ & $12.5 \%$ \\
\hline Leyomioma & 4 & 1 & 3 & 8 & $9.2 \%$ \\
\hline Non-GIST/non-leiomyosarcoma & 0 & 3 & 2 & 5 & $5.7 \%$ \\
\hline Plasma cell tumor & 0 & 0 & 2 & 2 & $2.3 \%$ \\
\hline \multicolumn{6}{|l|}{ Neuroendocrine } \\
\hline Neuroendocrine carcinoma (carcinoid) & 1 & 0 & 0 & 1 & $1.1 \%$ \\
\hline TOTAL & 14 & 22 & 50 & $88^{*}$ & $100 \%$ \\
\hline
\end{tabular}

* In two cases (a leiomyosarcoma and a GIST) the affected intestinal segment was not informed and the sample was too small to be determined histologically; SI = small intestine, $\mathrm{LI}=$ large intestine.

\section{Histological and immunohistochemical aspects of epithelial neoplasms}

Neoplasms of epithelial origin corresponded to $46.6 \%$ $(41 / 88)$ of the diagnoses of nonlymphoid GIN, of which carcinomas were the most frequently diagnosed $(97.6 \%, 40 / 41)$. They were mainly located in the LI $(57.5 \%, 23 / 40)$. Papillary adenocarcinoma was the main diagnostic, representing $41.5 \%$ $(17 / 41)$ of epithelial neoplasms, and they mainly involved the rectum. These neoplasms were mostly characterized by papillary projections lined by multiple layers of anaplastic columnar cells (Fig.1A). They were usually limited to the mucosa and neoplastic cells were observed throughout the submucosa in three cases and throughout the muscular region in one case.

Acinar (intestine) or tubular (stomach) adenocarcinoma was the second most common epithelial neoplasm, representing $24.4 \%(10 / 41)$ of the cases. Histologically, they were characterized by variably sized acinar structures replacing the mucosa, arising from hypercellular crypts, and often infiltrating the submucosal, muscular, and serous layers as groups or individual acinar structures (Fig.1B). A large amount of extracellular mucinous material was observed in $14.6 \%(6 / 41)$ of the cases, forming multiple agglomerates that sometimes replaced the mucosa and often invaded the submucosal, muscular, and serous layers, to be classified as mucinous adenocarcinoma (Fig.1C).

In $12.1 \%$ (5/41) of the cases, neoplastic epithelial cells were arranged in a solid pattern with moderate to severe pleomorphism and without glandular differentiation; these were classified as undifferentiated carcinomas. These neoplasms presented an infiltrative character with invasion of the submucosa and muscular layers (3/5), and occasionally the serous layer $(2 / 5)$. 


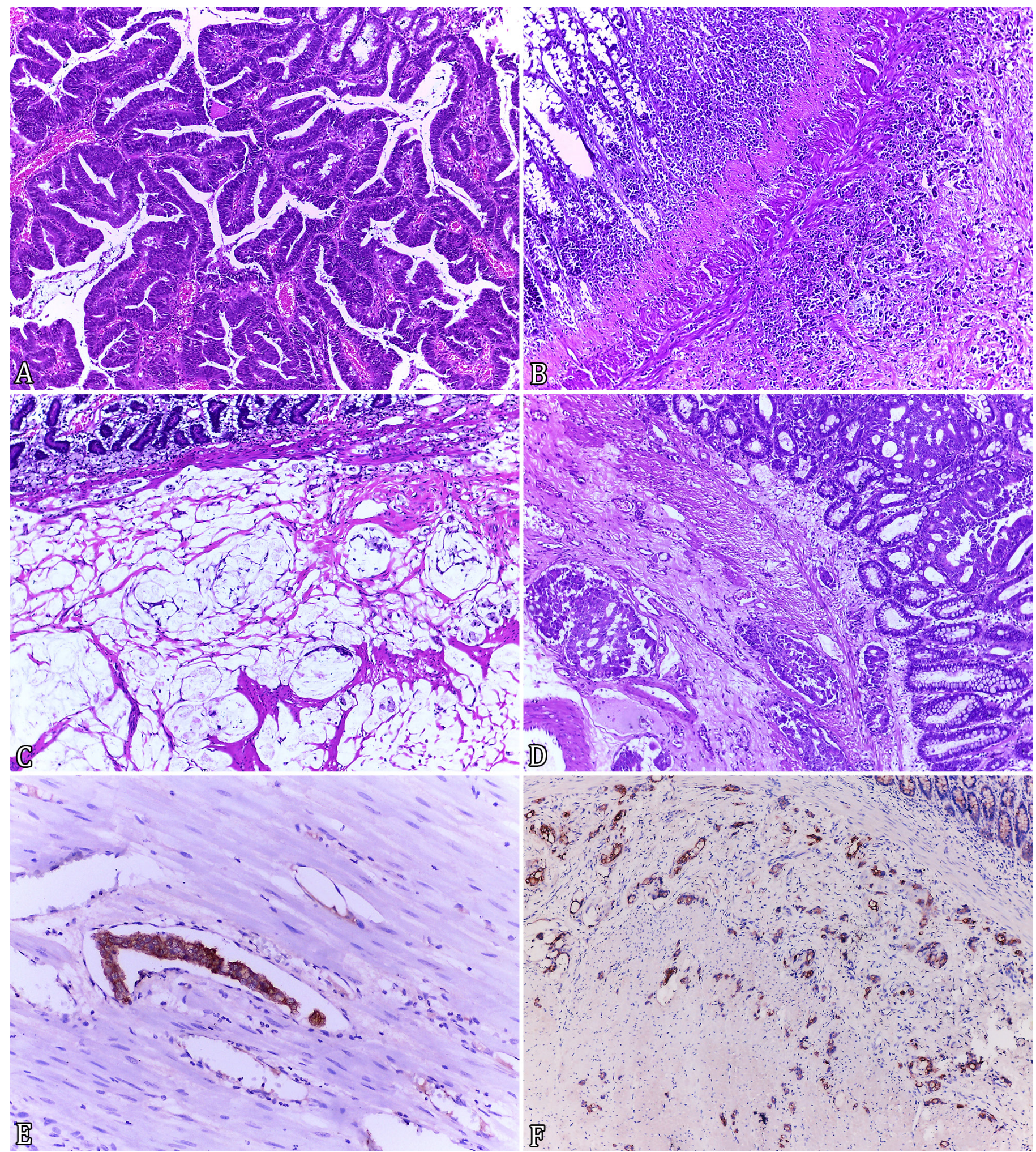

Fig.1. Epithelial gastrointestinal neoplasms. (A) Papillary adenocarcinoma. Neoplastic cells form multiple papillary projections that protrude into the intestinal lumen. HE, obj.20x. (B) Acinar adenocarcinoma. The mucosa is partially replaced with acinar structures, which invade the submucosa and muscular layers. HE, obj.10x. (C) Mucinous adenocarcinoma. The submucosal and muscular layers are replaced with large accumulations of extracellular mucin. HE, obj.10x. (D) Submucosal lymphatic vessels markedly distended and filled with neoplastic cells in an acinar adenocarcinoma. HE, obj.10x. (E) Acinar adenocarcinoma. Neoplastic cells evidenced inside the lymphatic vessels of the submucosa layer with staining for anti-pancytokeratin. IHC, 3-amino-9-ethylcarbazole (AEC), obj.20x. (F) Infiltrative neoplastic cells in an acinar adenocarcinoma highlighted in the submucosa and muscular layers by anti-pancytokeratin immunolabeling. IHC, AEC, obj.10x. 
In $4.9 \%(2 / 41)$ of the cases, neoplasms were classified as signet-ring cell carcinoma, in which the mucosa was replaced by an abundance of epithelial cells with a large cytoplasm filled with mucinous material that displaced the nucleus peripherally. These cells infiltrated the submucosa and muscular layers.

Neoplastic cells were often observed in the lymphatic vessels in epithelial nonlymphoid GIN (68.3\%, 28/41) (Fig.1D). These infiltrative cells were visualized in all neoplasms with acinar, mucinous, and signet-ring pattern, whereas only five of the 17 cases with papillary arrangement presented lymphatic invasion.

All carcinomas presented cytoplasmic or membrane immunolabeling against pancytokeratin, which varied from discrete to intense with no differences between the arrangements (Fig.1E,F).

\section{Histological and immunohistochemical aspects of mesenchymal neoplasms}

Mesenchymal neoplasms were diagnosed in 46.6\% (41/88) of the nonlymphoid GIN cases. Of these, the most frequently diagnosed were leiomyosarcoma $(36.6 \%, 15 / 41)$, GIST $(26.8 \%$,
$11 / 41)$, and leiomyoma (19.5\%, 8/41). Additionally, 78.0\% were malignant (32/41) and $22.0 \%$ were benign $(9 / 41)$.

Leiomyosarcomas $(36.6 \%, 15 / 41)$ mainly occupied the LI $(60.0 \%, 9 / 15)$. Of these, six were located in the cecum. Histologically, they were characterized by the proliferation of neoplastic cells, arranged in bundles in multiple directions, with high cell density and moderate to severe cellular and nuclear pleomorphism (Fig.2A,B).

Extensive areas of intratumoral necrosis, sometimes associated with hemorrhage and mineralization, were present in $46.7 \%(7 / 15)$ of the cases. They were primarily localized in the muscular layer and in $66.7 \%(10 / 15)$ they infiltrated the serosa, the submucosa in $53.4 \%(8 / 15)$, and extended to the mucosa in $40.0 \%(6 / 15)$. Invasion of neoplastic cells was occasionally observed in lymphatic vessels $(20.0 \%, 3 / 15)$. These were characterized immunohistochemically by intense, diffuse, and intracytoplasmic labeling against smooth muscle actin (Fig.2C).

In leiomyomas $(19.5 \%, 8 / 41)$, neoplastic cells formed a well-defined nodular structure restricted to the muscular layer. They were arranged in bundles mimicking normal smooth muscle tissues, with few pleomorphism (Fig.2D).
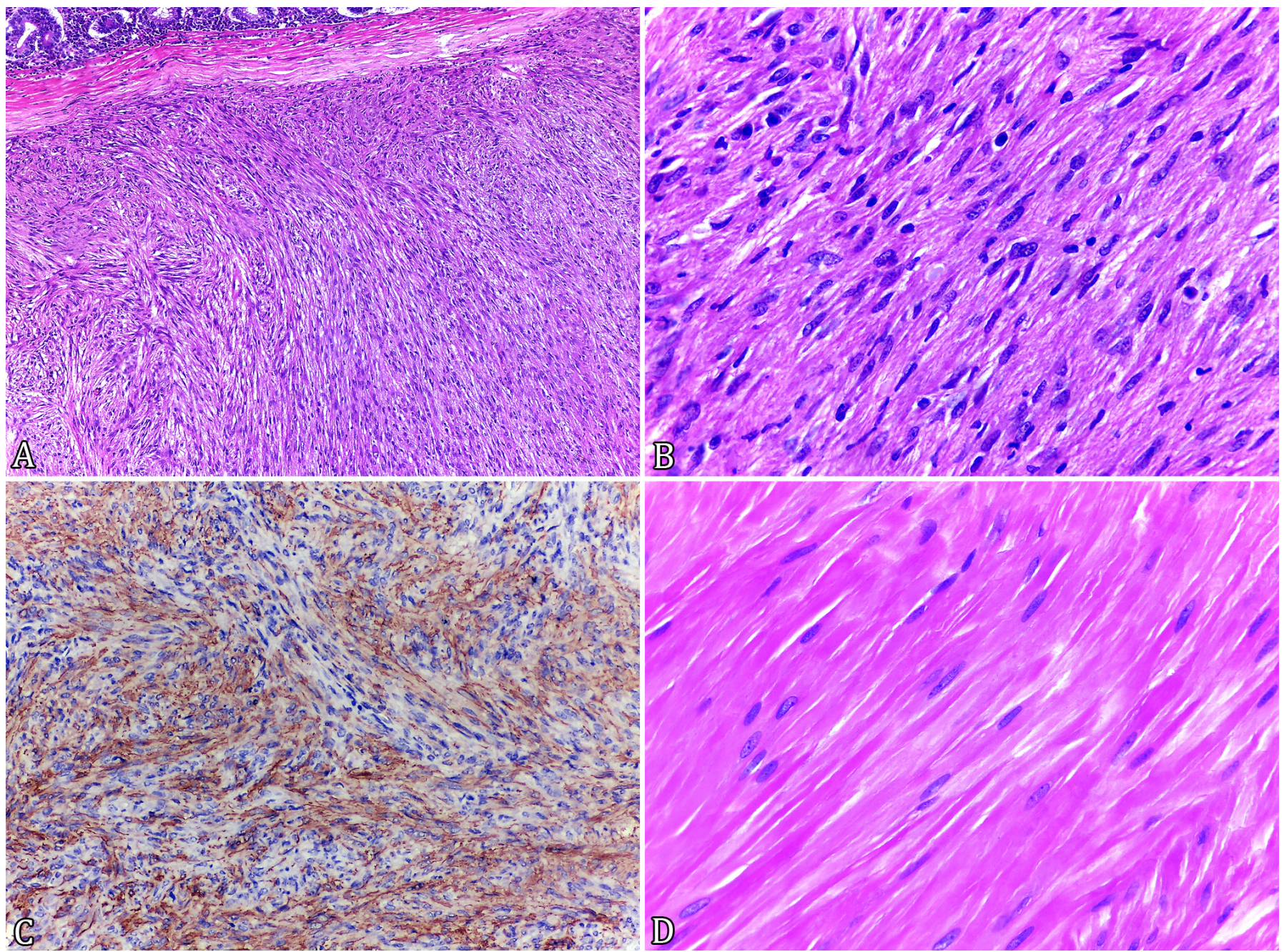

Fig.2. Mesenchymal gastrointestinal neoplasms of smooth muscle origin. (A) Leiomyosarcoma. Neoplastic cells are arranged in multidirectional bundles, replacing the muscular layer and infiltrating the submucosa. HE, obj.10x. (B) High cell density and pleomorphism in a leiomyosarcoma. HE, obj.40x. (C) Leiomyosarcoma. Neoplastic cells present intense immunolabeling for smooth muscle actin. IHC, 3-amino-9-ethylcarbazole (AEC), obj.20x. (D) Leiomyoma. Low cell density and low pleomorphism were observed. HE, obj.40x. 
All cases showed intense staining on IHC for smooth muscle actin, which was predominantly diffuse and discrete with multifocal areas of moderate and intracytoplasmic marking.

GISTs $(26.8 \%, 11 / 41)$ were mostly visualized in the LI $(63.6 \%, 7 / 11)$, of which five were in the cecum. Histologically, $54.5 \%(6 / 11)$ presented a fusiform pattern (Fig.3A) and $36.4 \%$ (4/11) showed an epithelioid pattern (Fig.3B). One GIST was highly pleomorphic and had a marked number of vacuoles, and was classified as pleomorphic (Fig.3C). All GISTs were densely cellular and occasionally showed perinuclear vacuolization. Extensive areas of intratumoral necrosis, sometimes with hemorrhage, were visualized in $81.8 \%(9 / 11)$ of the cases. One case presented invasion of lymphatic vessels. Immunohistochemically, the neoplasms showed positive labeling for c-Kit (Fig.3D), which was intracytoplasmic $(11 / 11)$ and diffuse $(10 / 11)$ or multifocal $(1 / 11)$, and ranged from discrete $(5 / 11)$, moderate $(2 / 11)$, and intense (4/11).

Five $(12.2 \%)$ of the mesenchymal neoplasms were classified as non-GIST/non-leiomyosarcomas. Of these, all neoplasms showed immunoreactivity for vimentin and three were also positive for the S-100 protein; these were located in the SI and showed two different morphological patterns. Two of them were composed of mesenchymal cells arranged in bundles in different directions and were densely cellular with moderate anisocytosis and anisokaryosis. There were also extensive areas of intratumoral hemorrhage and necrosis. The other pattern was characterized by few mesenchymal cells set in a loose network of fibers with a myxoid stroma and marked anisocytosis and anisokaryosis. In all these cases, moderate and multifocal cytoplasmic immunostaining against S-100 protein was observed.

Hemangiosarcoma was diagnosed in $2.4 \%$ (1/41) of the mesenchymal neoplasms, in which neoplastic cells occasionally formed irregular vascular spaces filled with red blood cells, with solid areas. The neoplasm was located in the LI and presented multifocal and discrete immunolabeling for CD31.

Fibroma corresponded to $2.4 \%(1 / 41)$ of the mesenchymal neoplasms and showed well-delimited neoplastic proliferation of fusiform cells arranged in bundles in the submucosa. Immunohistochemically, the neoplasm showed discrete staining for vimentin and lack of smooth muscle actin immunolabeling. On Masson's Trichrome staining, the neoplasm showed an intense reaction, marked in blue.
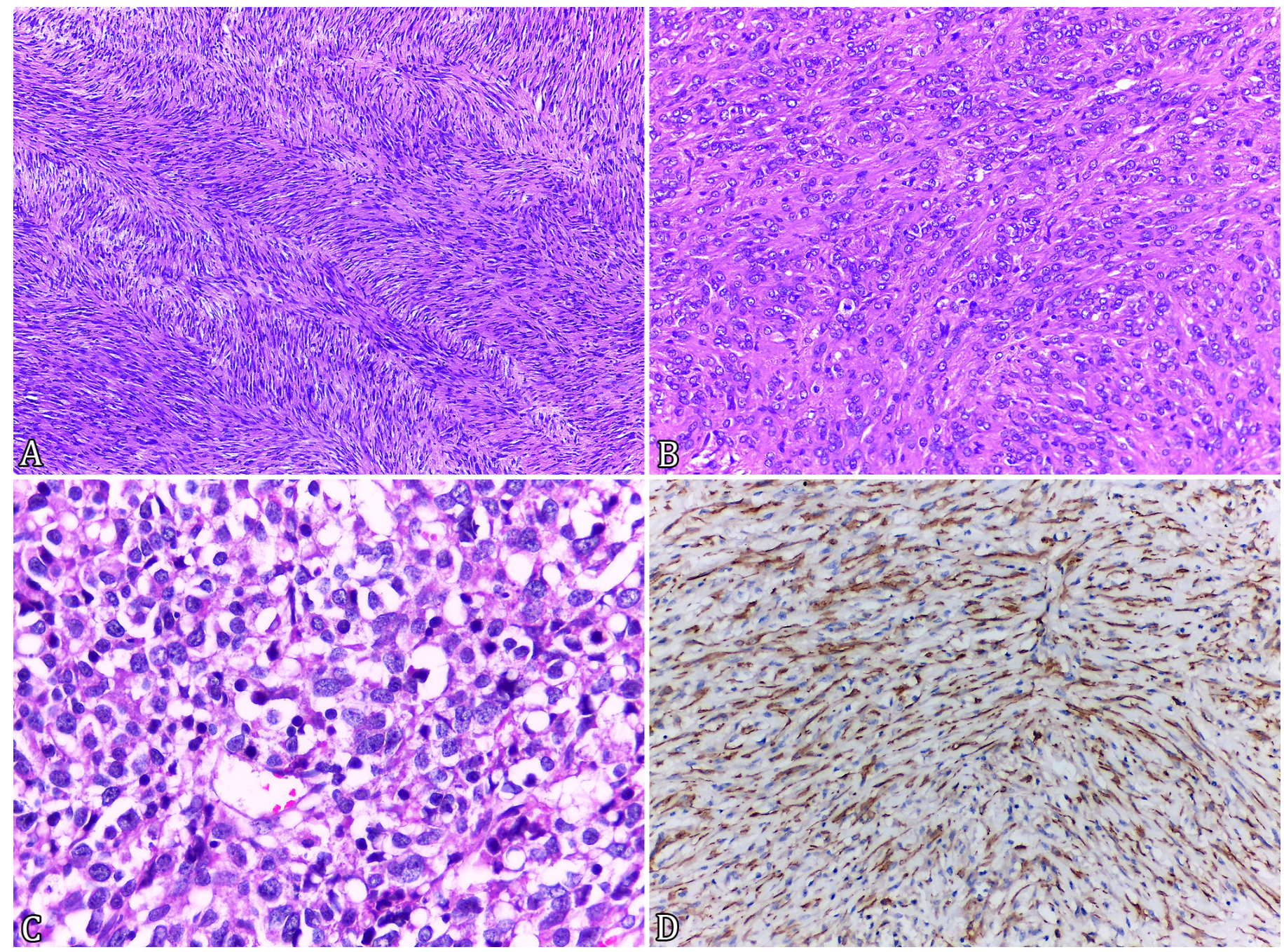

Fig.3. Mesenchymal gastrointestinal neoplasms, gastrointestinal stromal tumors (GISTs). (A) GIST with fusiform pattern. HE, obj.10x.

(B) GIST, epithelioid pattern. HE, obj.20x. (C) GIST exhibiting high pleomorphism, with a marked quantity of vacuoles. HE, obj.40x.

(D) Intense and diffuse IHQ anti-c-Kit staining on a fusiform GIST. IHC, 3-amino-9-ethylcarbazole (AEC), obj.20x. 


\section{Histological and immunohistochemical aspects of hematopoietic neoplasms}

Hematopoietic neoplasms corresponded to 5.7\% (5/88) of all nonlymphoid GIN. Of these, $80.0 \%(4 / 5)$ were located in the colorectal region. Sixty percent $(3 / 5)$ of the cases were diagnoses of mast cell tumors and $40.0 \%(2 / 5)$ were plasma cell tumors.

The mast cell tumors $(60.0 \%, 3 / 5)$ were located in the submucosa and had invaded through the mucosa, muscular, and serous layers. They were mostly characterized by round cells rarely containing intracytoplasmic granules, with moderate pleomorphism, and moderate and focal immunolabeling for intracytoplasmic c-kit (Fig.4A,B).

Plasma cell tumors $(40.0 \%, 2 / 5)$ were characterized by round cells with broad and eosinophilic cytoplasm, eccentric nuclei, and were located in the submucosa, extending to the mucosa and muscular layers (Fig.4C). In one case, abundant deposition of amyloid was observed, which was evidenced by the histochemical stain Red-Congo (Fig.4D), and one case presented discrete and multifocal CD79 $\alpha$ cy immunolabeling in the IHC. No invasion of lymphatic vessels was observed.
Histological and immunohistochemical aspects of neuroendocrine neoplasms

Carcinoma of neuroendocrine origin was found in 1.1\% $(1 / 88)$ of the cases. Neoplastic cells were characterized by poorly delimited proliferation in the submucosa and muscular layers of the stomach, formed by cells arranged in solid nests supported by thin fibrovascular stroma with moderate pleomorphism. Multifocal areas of intratumoral necrosis and mineralization were visualized. In IHC, discrete intracytoplasmic multifocal marking was observed for neuron-specific enolase.

\section{DISCUSSION}

The present study describes the epidemiological, pathological, and immunohistochemical findings of canine nonlymphoid GIN. Nonlymphoid GIN constituted $0.6 \%$ of neoplasms and $0.4 \%$ of total canine biopsies in the analyzed period, confirming the fact that these neoplasms involved an uncommon diagnosis in this species. Previous studies have shown frequencies of $0.2 \%$ to $3.0 \%$ (Patnaik et al. 1977, Penninck et al. 1998, Munday et al. 2017).
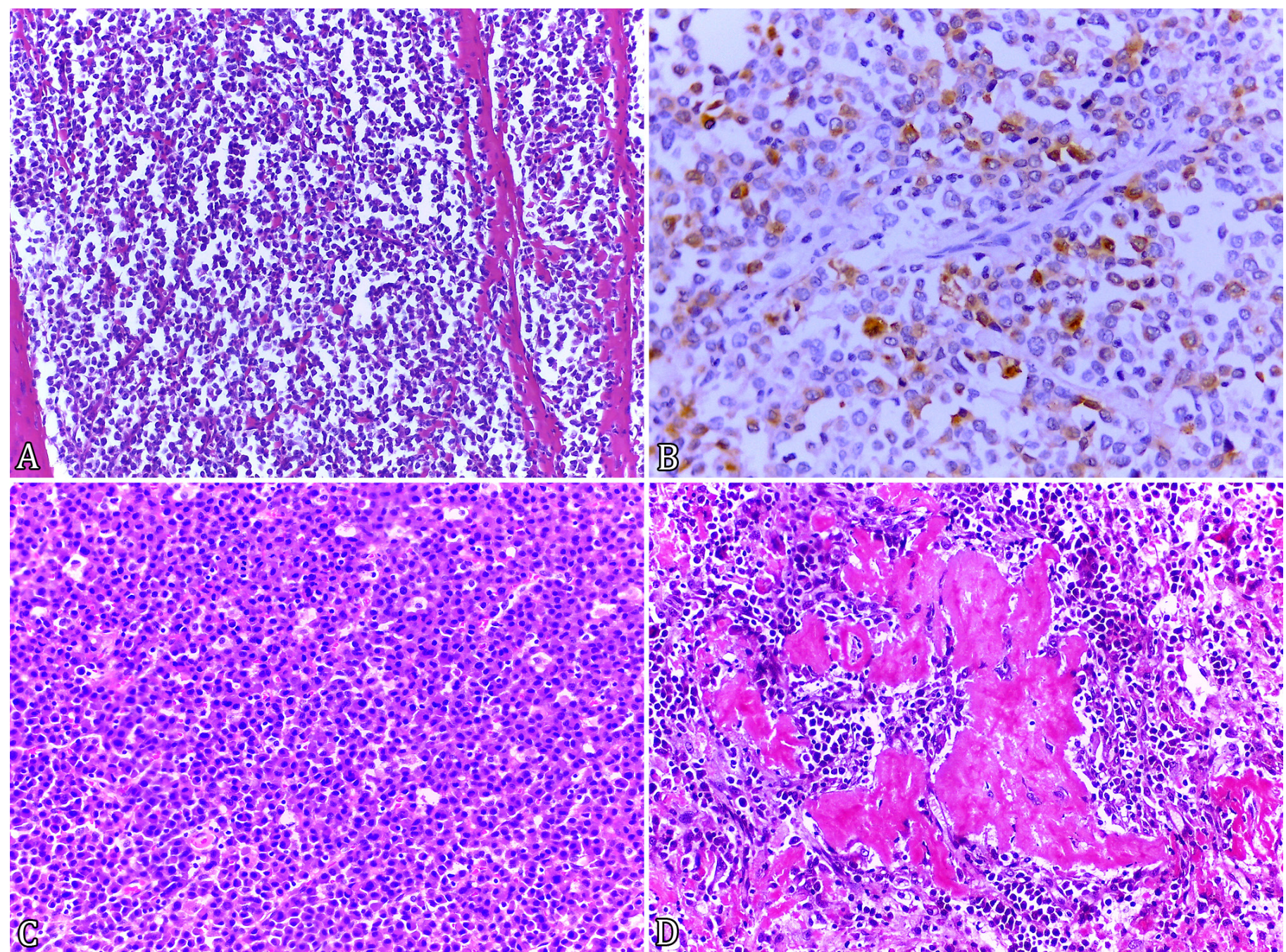

Fig.4. Hematopoietic mesenchymal neoplasms. (A) Mast cell tumor. Neoplastic proliferation of round cells arranged in cords infiltrating the muscular layer. HE, obj.20x (B) Mast cell tumor. Moderate and multifocal cytoplasmic staining for c-Kit. IHQ, 3-amino-9-ethylcarbazole (AEC), obj.20x. (C) Plasma cell tumor, characterized by round neoplastic cells containing broad and eosinophilic cytoplasm. HE, obj.20x. (D) Plasma cell tumor. Deposition of amyloid to neoplastic cells evidenced by Red-Congo histochemical staining, obj.20x. 
Pure-bred dogs were more affected than non-breed dogs, as reported by other studies (Patnaik et al. 1977, Frost et al. 2003, Maas et al. 2007). The age varied from 1 to 17 years, with a median age of 10 years, which concurs with the fact that these neoplasms mostly occur in middle-aged to older dogs (Patnaik et al. 1977, LaRock \& Ginn 1997, Swann \& Holt 2002, Bettini et al. 2003, Russell et al. 2007, Hayes et al. 2013, Munday et al. 2017).

Although some studies have reported that the occurrence of GIN of epithelial origin is more common than that of mesenchymal origin (Bettini et al. 2003), the frequency of mesenchymal diagnoses in this study was similar to that of epithelial GIN. This shows that mesenchymal neoplasms are also important in dogs and should always be considered as a differential diagnosis in the species. However, when the diagnoses were individually analyzed, carcinomas were the most frequent, similar to those described in the literature (Patnaik et al. 1977, Head et al. 2003, Munday et al. 2017).

Both epithelial and mesenchymal neoplasms mainly involved the intestine. Although the LI comprises the smallest segment of the canine intestinal tract, it was the main site of development for both carcinomas and sarcomas. The reason for the low occurrence of neoplasms in the SI compared to the LI is still uncertain, but some hypotheses based on microenvironmental differences have been proposed in humans (Maguire \& Sheahan 2018). The much quicker transit time of intestinal contents in the SI than in the LI reduces mucosal exposure to carcinogenic agents, and the concentration of these is diluted in the largest volume of secretions (Lowenfels 1973, Crawshaw et al. 1998). Furthermore, the bacterial population in the SI is smaller and metabolically inactive, and therefore may not be able to transform pre-cancerous substances into carcinogens (Lowenfels 1973, Pan \& Morrison 2011).

Malignant neoplasms were the most frequent observed in this study. Researchers report that malignant presentation is considered more common in the gastrointestinal tract compared to benign presentation (Patnaik et al. 1977). Regardless of cellular origin, benign tumors are differentiated from carcinomas and sarcomas based on morphologic features such as increased cellularity with a high nucleus/cytoplasm ratio, anisocytosis and anisokaryosis, abundant or atypical mitosis figures, and the presence of invasion or metastasis (Gillespie et al. 2011).

The benign neoplasms corresponded almost entirely to neoplasms of smooth muscle origin. The leiomyomas equally involved the stomach and intestine, diverging from what is mentioned in literature, where authors report that the most common site of this neoplasm is the stomach (Patnaik et al. 1977, Bettini et al. 2003, Munday et al. 2017). However, considering that biopsy samples were used in this study and that leiomyomas usually do not lead to clinical signs and are not surgically removed, the number of gastric leiomyomas was probably underestimated in this study. Benign neoplasms such as fibroids and adenomas are rarely reported in dogs (Head et al. 2003, Munday et al. 2017). As in humans, adenomas are considered pre-malignant lesions, and it can be speculated that adenomas occur in dogs much more frequently than is recognized, but are detected only when their transformation to adenocarcinoma has occurred, resulting in clinical disease (Munday et al. 2017).
Adenocarcinomas are the most common intestinal neoplasms in dogs (Head et al. 2003, Uzal et al. 2016). In this study, these neoplasms corresponded to half of the diagnoses in the stomach, and almost half of the diagnoses in the intestine, occurring predominantly in the rectum. These results contrast with those of other authors who mention that adenocarcinomas occur predominantly in the SI, mainly in the duodenum and jejunum (Crawshaw et al. 1998, Paoloni et al. 2002, Munday et al. 2017).

Adenocarcinomas are often in an advanced stage of evolution due to late diagnosis, and already occupy deeper layers of the stomach and intestine (Munday et al. 2017), which explains the large number of cases with intestinal layer infiltration and lymphatic invasion in epithelial neoplasms in this study. In humans, the type of arrangement seems to be involved in the chance of metastases, since neoplasms that project to the lumen have much smaller capacity for lymphatic invasion and metastasis than those that grow first toward the gastric or intestinal wall (Goldblum 2018). In this study, of the 17 papillary adenocarcinomas only five infiltrated the deeper layers and lymphatic vessels, whereas those with an acinar, mucinous, signet ring, and undifferentiated arrangement often invaded and replaced the intestinal layers, and all invaded the lymphatic vessels. Therefore, neoplasms in these arrangements may present a greater invasive potential compared to that of the papillary arrangement.

All carcinomas showed immunostaining for pancytokeratin. IHC for pancytokeratin is an important diagnostic tool to confirm an epithelial origin, especially in cases where neoplasms are undifferentiated, as well as to facilitate the identification of infiltrative cells in deeper layers or to highlight small numbers of neoplastic cells in small biopsy samples (Munday et al. 2017).

Leiomyosarcomas corresponded to the second most common neoplasm and to the main sarcoma. They were mainly located in the LI, which differs from the observation in some studies that consider these neoplasms rare in the intestine (Bettini et al. 2003) and common in the stomach (Russell et al. 2007). Another study describes the cecum as the main localization of leiomyosarcomas (Cohen et al. 2003). Leiomyosarcomas have slow growth and often have areas of necrosis and hemorrhage (Munday et al. 2017), as observed in this study.

Leiomyosarcomas often resemble GISTs in histopathology, especially when GISTs have a fusiform pattern. Therefore, IHC is indicated for a more definite diagnosis of mesenchymal gastrointestinal neoplasms (Munday et al. 2017). Immunostaining for c-Kit defines the diagnosis of GIST, whereas lack of c-Kit expression and immunolabeling for smooth muscle actin defines a leiomyosarcoma (Maas et al. 2007, Hayes et al. 2013). However, IHC reactivity for smooth muscle actin alone should not be used for a definitive diagnosis for leiomyosarcoma, because a part of GISTs may also express smooth muscle markers and neural origin (Bettini et al. 2003, Frost et al. 2003, Maas et al. 2007, Hayes et al. 2013).

Prior studies on the identification of GISTs consider that the most common nonlymphoid mesenchymal neoplasms of the gastrointestinal tract in dogs are neoplasms of smooth muscle origin (Patnaik et al. 1977, Birchard 1986, LaRock \& Ginn 1997, Crawshaw et al. 1998). However, after the discovery of c-Kit expression by GISTs, some studies have reclassified the tumors using IHC, and have demonstrated that the 
majority of these tumors corresponded to GISTs (Maas et al. 2007, Russell et al. 2007, Hayes et al. 2013) and that these leiomyosarcoma diagnoses are overestimated. However, in the present study, despite the use of IHC, leiomyosarcomas were more frequent, which corroborates with the findings in literature (Patnaik et al. 1977, Birchard 1986, LaRock \& Ginn 1997, Crawshaw et al. 1998).

GISTs comprised the second most frequent mesenchymal neoplasm, different from that described by some authors (Bettini et al. 2003, Maas et al. 2007, Hayes et al. 2013). In humans, GISTs are more common in the stomach (Miettinen \& Lasota 2001) whereas in dogs, GISTs are found preferentially in the intestine with occasional reports in the stomach (Bettini et al. 2003, Frost et al. 2003, Maas et al. 2007, Gillespie et al. 2011, Hayes et al. 2013). These neoplasms can be classified histologically based on four morphological patterns, as described in humans: fusiform, myxoid, fascicular, and epithelioid (Head et al. 2003, Miettinen \& Lasota 2003). Only the fusiform and epithelioid types are described in dogs, and the fusiform pattern is reported as the most common (Hayes et al. 2013), as observed in this study. Additionally, perinuclear vacuolization is a common feature of GISTs and is occasionally very prominent (Miettinen \& Lasota 2003), and may be considered as a factor to histologically differentiate them from other sarcomas.

Five neoplasms were classified as non-GIST / non-leiomyosarcoma based on the lack of expression for c-Kit and smooth muscle actin. Immunolabeling for vimentin was observed, similar to that found by other authors (Russell et al. 2007, Hayes et al. 2013). In addition, three cases were also immunoreactive for the S-100 protein, and had a histological pattern of peripheral nerve sheath tumors, and were reminiscent of an Antoni A and/or Antoni B pattern. However, as a neurogenic origin of these neoplasms often cannot be confirmed, it is currently suggested that they be included in the non-GIST/non-leiomyosarcoma group, with S-100 immunostaining (Hayes et al. 2013). Although relatively common in other locations, nerve sheath tumors are rarely described in the gastrointestinal tract of dogs (Schöniger \& Summers 2009).

Mast cell tumors are uncommon in dogs and are generally more aggressive than their cutaneous counterparts (Patnaik et al. 1980b, Munday et al. 2017). They may involve any intestinal segment, but are more common in the SI (Head et al. 2003). When cytoplasmic granules are not easily visualized, c-Kit immunohistochemistry may aid in their diagnosis (Reguera et al. 2000, Ozaki et al. 2002).

Extramedullary plasma cell tumors located in the gastrointestinal tract are rare in dogs and are found more frequently in the colorectal region (Ramos-Vara et al. 1998, Head et al. 2003). Histologically, they are easily recognized as tumors of round cells with eosinophilic cytoplasm and eccentric nuclei (Kupanoff et al. 2006, Munday et al. 2017); however, anti-CD79 $\alpha$ cy IHC for B lymphocytes can be used as an auxiliary diagnostic method when there is little differentiation (Ramos-Vara et al. 1998). Although uncommon, plasma cell tumors may show amyloid deposition (Rowland et al. 1991, Kupanoff et al. 2006). A neoplasm in this study did not show reactivity for $\mathrm{CD} 7 \alpha c y$, probably due to the prolonged fixation time of the sample, but the cellular morphology along with amyloid deposition evidenced by red-Congo staining was considered sufficient for the diagnosis. Most neoplasms tend to be restricted to the submucosa, but some plasma cell tumors exhibit a more aggressive behavior including invasion of the muscular tunica (Uzal et al. 2016), as observed.

Neuroendocrine neoplasms originate from gastrointestinal enteroendocrine cells and are very uncommon in the gastrointestinal tract (Munday et al. 2017). Although there are few reports, these tumors show an aggressive behavior. In one study evaluating four intestinal carcinoids, all cases had distant metastases (Patnaik et al. 1980a). Use of cell morphology is not indicated to evaluate prognosis, because despite the malignant behavior that these neoplasms often demonstrate, they present cellular atypia and high mitotic indexes only in some cases (Munday et al. 2017). To confirm the neuroendocrine origin, IHC for chromogranin A, neuron-specific enolase, synaptophysin, or PGP 9.5 is indicated (Head et al. 2003, Sako et al. 2003). In the present study, labeling for neuron-specific enolase was sufficient to confirm the diagnosis.

\section{CONCLUSIONS}

Nonlymphoid gastrointestinal neoplasms occurred mainly in middle-aged to older dogs, mostly purebred, and male. They affected the intestine more than the stomach, especially the LI. The rectum was the main site for the development of carcinomas whereas the cecum was the main site for sarcomas. The stomach was an important site for the development of smooth muscle neoplasms, mainly leiomyomas.

Malignant neoplasms were more common, and the main neoplasm observed was adenocarcinoma, followed by leiomyosarcoma and GIST. Epithelial neoplasms showed a greater potential for lymphatic invasion whereas mesenchymal cells appeared to be more expansive with intratumoral necrosis and hemorrhage.

Immunohistochemistry proved to be an important tool for confirming the cellular type involved in gastrointestinal neoplasms, as well as for the identification of infiltrating neoplastic cells in the case of carcinomas, and an indispensable technique for the definitive diagnosis of sarcomas.

Acknowledgments.- The authors thank the "Conselho Nacional de Desenvolvimento Científico e Tecnológico" (CNPq) and "Coordenação de Aperfeiçoamento de Pessoal de Nível Superior" (CAPES) for supporting this study.

Conflict of interest statement.- The authors declare no conflict of interest with respect to the publication of this paper.

\section{REFERENCES}

Bettini G., Morini M. \& Marcato P.S. 2003. Gastrointestinal spindle cell tumours of the dog: histological and immunohistochemical study. J. Comp. Pathol. 129(4):283-293. <http://dx.doi.org/10.1016/S0021-9975(03)00046-X> <PMid:14554126>

Birchard S.J. 1986. Nonlymphoid intestinal neoplasia in 32 dogs and 14 cats J. Am. Anim. Hosp. Assoc. 22:533-537.

Cohen M., Post G.S. \& Wright J.C. 2003. Gastrointestinal leiomyosarcoma in 14 dogs. J. Vet. Intern. Med. 17(1):107-110. <http://dx.doi. org/10.1111/j.1939-1676.2003.tb01331.x><PMid:12564735>

Crawshaw J., Berg J., Sardinas J.C., Engler S.J., Rand W.M., Ogilvie G.K., Spodnick G.J., O’Keefe D.A., Vail D.M. \& Henderson R.A. 1998. Prognosis for dogs with nonlymphomatous, small intestinal tumors treated by 
surgical excision. J. Am. Anim. Hosp. Assoc. 34(6):451-456. <http://dx.doi. org/10.5326/15473317-34-6-451> <PMid:9826278>

Demetri G.D., von Mehren M., Blanke C.D., Van den Abbeele A.D., Eisenberg B., Roberts P.J., Heinrich M.C., Tuveson D.A., Singer S., Janicek M., Fletcher J.A., Silverman S.G., Silberman S.L., Capdeville R., Kiese B., Peng B., Dimitrijevic S., Druker B.J., Corless C., Fletcher C.D. \& Joensuu H. 2002. Efficacy and safety of imatinib mesylate in advanced gastrointestinal stromal tumors. N. Engl. J. Med. 347(7):472-480. <http://dx.doi.org/10.1056/NEJMoa020461> $<$ PMid:12181401>

Fonda D., Gualtieri M. \& Scanziani E. 1989. Gastric carcinoma in the dog: a clinicopathological study of 11 cases. J. Small Anim. Pract. 30(6):353-360. <http://dx.doi.org/10.1111/j.1748-5827.1989.tb01579.x>

Frgelecová L., Škorič M., Fictum P. \& Husník R. 2014. Canine gastrointestinal tract tumours: a restrospective study of 74 cases. Acta Vet. Brno. 82(4):387392. <http://dx.doi.org/10.2754/avb201382040387>

Frost D., Lasota J. \& Miettinen M. 2003. Gastrointestinal stromal tumors and leiomyomas in the dog: a histopathologic, immunohistochemical and molecular genetic study of 50 cases. Vet. Pathol. 40(1):42-54. <http:// dx.doi.org/10.1354/vp.40-1-42><PMid:12627712>

Gillespie V., Baer K., Farrelly J., Craft D. \& Luong R. 2011. Canine gastrointestinal stromal tumors: immunohistochemical expression of CD34 and examination of prognostic indicators including proliferation markers Ki67 and AgNOR. Vet. Pathol. 48(1):283-291. <http://dx.doi.org/10.1177/0300985810380397> <PMid:20826846>

Goldblum J.R. 2018. Large bowel, p.648-702. In: Goldblum J.R., Lamps L.W., McKenney J.K. \& Myers J.L. (Eds), Rosai and Ackerman's Surgical Patholoy. 11th ed. Elsevier, Philadelphia.

Hayes S., Yuzbasiyan-Gurkan V., Gregory-Bryson E. \& Kiupel M. 2013. Classification of canine nonangiogenic, nonlymphogenic, gastrointestinal sarcomas based on microscopic, immunohistochemical, and molecular characteristics. Vet. Pathol.50(5):779-788. <http://dx.doi.org/10.1177/0300985813478211> <PMid:23456969>

Head K.W., Cullen J.M., Dubielzig R.R., Else R.W., Misdorp W., Patnaik A.K., Tateyama S. \& Van der Gaag I. 2003. Histological Classification of Tumors of the Alimentary System of Domestic Animals. Vol.10. 2nd ed. Armed Forces Institute of Pathology, Washington, p.73-110.

Kindblom L.G., Remotti H.E., Aldenborg F. \& Meis-Kindblom J.M. 1998. Gastrointestinal pacemaker cell tumor (GIPACT): gastrointestinal stromal tumors show phenotypic characteristics of the interstitial cells of Cajal. Am. J. Pathol. 152(5):1259-1269. <PMid:9588894>

Kupanoff P.A., Popovitch C.A. \& Goldschmidt M.H. 2006. Colorectal plasmacytomas: a retrospective study of nine dogs. J. Am. Anim. Hosp. Assoc. 42(1):37-43. <http://dx.doi.org/10.5326/0420037> <PMid:16397193>

LaRock R.G. \& Ginn P.E. 1997. Immunohistochemical staining characteristics of canine gastrointestinal stromal tumors. Vet. Pathol. 34(4):303-311. <http://dx.doi.org/10.1177/030098589703400406><PMid:9240839>

Lowenfels A. 1973. Why are small-bowel tumours so rare? Lancet. 301(7793):24-26. <http://dx.doi.org/10.1016/S0140-6736(73)912282> <PMid:4118541>

Maas C.P., Ter-Haar G., Van-Der-Gaag I. \& Kirpensteijn J. 2007. Reclassification of small intestinal and cecal smooth muscle tumors in 72 dogs: clinical, histologic, and immunohistochemical evaluation. Vet. Surg. 36(4):302-313. <http://dx.doi.org/10.1111/j.1532-950X.2007.00271.x><PMid:17547593>

Maguire A. \& Sheahan K. 2018. Primary small bowel adenomas and adenocarcinomas - recent advances. Virchows Arch. 473(3):265-273. <http://dx.doi.org/10.1007/s00428-018-2400-7> <PMid:29998424>

Miettinen M. \& Lasota J. 2001. Gastrointestinal stromal tumors-definition, clinical, histological, immunohistochemical and molecular genetic features and differential diagnosis. Virchows Arch. 438(1):1-12. <http://dx.doi. org/10.1007/s004280000338><PMid:11213830>

Miettinen M. \& Lasota J. 2003. Gastrointestinal stromal tumors (GISTs): definition, occurrence, pathology, differential diagnosis and molecular genetics. Pol. J. Pathol. 54(1):3-24. <PMid:12817876>

Munday J.S., Löhr C.V. \& Kiupel M. 2017. Tumors of the alimentary tract, p.499-601. In: Meuten D.J. (Ed.), Tumors in Domestic Animals. 5th ed. Wiley Blackwell, Ames.

Ozaki K., Yamagami T., Nomura K. \& Narama I. 2002. Mast cell tumors of the gastrointestinal tract in 39 dogs. Vet. Pathol. 39(5):557-564. <http:// dx.doi.org/10.1354/vp.39-5-557> <PMid:12243465>

Pan S.Y. \& Morrison H. 2011. Epidemiology of cancer of the small intestine. World J. Gastrointest. Oncol. 3(3):33-42. <http://dx.doi.org/10.4251/ wjgo.v3.i3.33><PMid:21461167>

Paoloni M.C., Penninck D.G. \& Moore A.S. 2002. Ultrasonographic and clinicopathologic findings in 21 dogs with intestinal adenocarcinoma. Vet. Radiol. Ultrasound 43(6):562-567. <http://dx.doi.org/10.1111/j.1740-8261.2002. tb01050.x><PMid:12502112>

Patnaik A.K., Hurvitz A.I. \& Johnson G.F. 1977. Canine gastrointestinal neoplasms. Vet. Pathol. 14(6):547-555.<http://dx.doi.org/10.1177/030098587701400602> $<$ PMid:579266>

Patnaik A.K., Hurvitz A.I. \& Johnson G.F. 1978. Canine gastric adenocarcinoma. Vet. Pathol.15(5):600-607.<http://dx.doi.org/10.1177/030098587801500503> $<$ PMid:716156>

Patnaik A.K., Hurvitz A.I. \& Johnson G.F. 1980a. Canine intestinal adenocarcinoma and carcinoid. Vet. Pathol.17(2):149-163.<http://dx.doi. org/10.1177/030098588001700204><PMid:7361376>

Patnaik A.K., Twedt D.C. \& Marretta S.M. 1980b. Intestinal mast cell tumour in a dog. J. Small Anim. Pract. 21(4):207-212. <http://dx.doi. org/10.1111/j.1748-5827.1980.tb01237.x><PMid:6768929>

Penninck D.G., Moore A.S. \& Gliatto J. 1998. Ultrasonography of canine gastric epithelial neoplasia. Vet. Radiol. Ultrasound 39(4):342-348. <http://dx.doi. org/10.1111/j.1740-8261.1998.tb01618.x><PMid:9710139>

Ramos-Vara J.A., Miller M.A., Pace L.W., Linke R.P., Common R.S. \& Watson G.L. 1998. Intestinal multinodular $\mathrm{A} \lambda$ amyloid deposition associated with extramedullary plasmacytoma in three dogs: clinicopathological and immunohistochemical studies. J. Comp. Pathol. 119(3):239-249. <http:// dx.doi.org/10.1016/S0021-9975(98)80047-9><PMid:9807726>

Reguera M.J., Rabanal R.M., Puigdemont A. \& Ferrer L. 2000. Canine mast cell tumors express stem cell factor receptor. Am. J. Dermatopathol. 22(1):49-54. <http://dx.doi.org/10.1097/00000372-200002000-00010> <PMid:10698217>

Rowland P.H., Valentine B.A., Stebbins K.E. \& Smith C.A. 1991. Cutaneous plasmacytomas with amyloid in six dogs. Vet. Pathol. 28(2):125-130. <http://dx.doi.org/10.1177/030098589102800204><PMid:1712141>

Russell K.N., Mehler S.J., Skorupski K.A., Baez J.L., Shofer F.S. \& Goldschmidt M.H. 2007. Clinical and immunohistochemical differentiation of gastrointestinal stromal tumors from leiomyosarcomas in dogs: 42 cases (1990-2003). J. Am. Vet. Med. Assoc. 230(9):1329-1333. <http://dx.doi.org/10.2460/ javma.230.9.1329><PMid:17472558>

Sako T., Uchida E., Okamoto M., Yamamoto E., Kagawa Y., Yoshino T., Hirayama K. \& Taniyama H. 2003. Immunohistochemical evaluation of a malignant intestinal carcinoid in a dog. Vet. Pathol. 40(2):212-215. <http://dx.doi. org/10.1354/vp.40-2-212><PMid:12637763>

Schöniger S. \& Summers B.A. 2009. Localized, plexiform, diffuse, and other variants of neurofibroma in 12 dogs, 2 horses, and a chicken. Vet. Pathol. 46(5):904-915. <http://dx.doi.org/10.1354/vp.08-VP-0322-S-FL> <PMid:19429995> 
Swann H.M. \& Holt D.E. 2002. Canine gastric adenocarcinoma and leiomyosarcoma: a retrospective study of 21 cases (1986-1999) and literature review. J. Am. Anim. Hosp. Assoc. 38(2):157-164. <http://dx.doi. org/10.5326/0380157><PMid:11908834>

Uzal F.A., Plattner B.L. \& Hostetter J.M. 2016. Alimentary system, p.1-257. In: Maxie M.G. (Ed.), Jubb, Kennedy and Palmer's Pathology of Domestic Animals. Vol.2. 6th ed. Elsevier, St Louis. <http://dx.doi.org/10.1016/ B978-0-7020-5318-4.00007-3>. van Oosterom A.T., Judson I., Verweij J., Stroobants S., Donato di Paola E., Dimitrijevic S., Martens M., Webb A., Sciot R., Van Glabbeke M., Silberman S., Nielsen O.S. \& European Organisation for Research and Treatment of Cancer Soft Tissue and Bone Sarcoma Group. 2001. Safety and efficacy of imatinib (STI571) in metastatic gastrointestinal stromal tumours: a phase I study. Lancet. 358(9291):1421-1423.<http://dx.doi.org/10.1016/S01406736(01)06535-7><PMid:11705489> 